\title{
Stakeholder Groups of Public and Private Universities in the Czech Republic - Identification, Categorization and Prioritization
}

\author{
Marie Slabá1
}

\begin{abstract}
With regard to changes in the environment of tertiary education and tertiary educational systems, universities are now unlikely to succeed as 'separated closed' institutions that are unresponsive to their environment and stakeholders. Stakeholder analysis is considered as an important part of university management and marketing and universities have to take care of key stakeholder groups and build long term relationships with them. This paper focuses on the stakeholder analysis and adopts the stakeholder theory and analysis for the needs of the Czech market of tertiary education. This paper analyses results of the author's online questionnaire that provided the input for data analysis deploying basic descriptive analysis and first steps of stakeholder analysis - identification, categorization and prioritization. Results of author's research show that there are only slight differences between public and private universities and their perspective concerning generic stakeholder groups of universities. However the research revealed two controversial stakeholder groups - donors and competitors. In comparison with other stakeholder groups perception of these two stakeholder groups by public and private universities is very different. Stakeholder groups of public and private universities were categorized into four basic groups - primary internal stakeholder groups, primary external stakeholder groups, secondary internal stakeholder groups, and secondary external stakeholder groups. Primary internal and external stakeholder groups which are crucial for survival of universities are the most important stakeholder groups for universities. The author identified ten most important stakeholder groups for public and private universities separately, based on assigned priorities that will be used for further research.
\end{abstract}

Key words: stakeholder, university, stakeholder management, stakeholder group

JEL Classification: I29, M19, M39

Received: 25 August 2014 / Accepted: 1 September 2015 / Published: 30 September 2015

\footnotetext{
${ }^{1}$ Institute of Technology and Business in České Budějovice, Department of Tourism and Marketing, Okružní 10, 37001 České Budějovice, e-mail: slaba@mail.vstecb.cz
}

(C) 2015 by the authors; licensee Review of Economic Perspectives / Národohospodářský obzor, Masaryk University, Faculty of Economics and Administration, Brno, Czech Republic. This article is an open access article distributed under the terms and conditions of the Creative Commons Attribution 3.0 license, Attribution - Non Commercial - No Derivatives. 


\section{Introduction}

Universities and other tertiary education institutions have had to fundamentally change not only in the Czech Republic but also all over the world during last years as new trends and lots of changes in the market of tertiary education appeared. The tertiary education market is affected by the growing competition, decreasing enrolments, globalisation, changes in the tertiary education systems, negative trend of demographic curve in developed countries, emphasis on international comparisons of universities, consequences of global economic and financial crises that affected mainly university funding, decrease in public expenditures on educational institutions, etc.(Anderson, Iriggs, Burton, 2001; OECD, 2013; Park, 2011; Lumby, Foskett, 1999).

These changes in the structure of the market of tertiary education and the tertiary educational system around the globe have resulted in new approaches to university management and responsibilities for educational managers (Anderson, Iriggs, Burton, 2001). Universities and other tertiary education institutions have been confronted with increasing outside pressure aimed at university change (Amaral, Magalhães, 2002). As Park stated, "in recent years, much attention has been paid to the idea of academic capitalism and the notion of the entrepreneurial university" (Park, 2011, p. 84). The competition of public and lots of new private universities, increasing pressure, etc. brought a business orientation to the management of universities, all basic strategic decisions, marketing management and communication and building relationships with all interested groups stakeholder groups in the Czech Republic, too.

Stakeholder management including stakeholder identification, prioritization, categorization and analysis can be considered as one of these new business orientations in university management and marketing management.

This paper focuses on identification, categorization and prioritization of key stakeholder groups of public and private universities in the Czech Republic. Therefore, it is necessary to first make a brief introduction to the stakeholder theory.

"The word 'stakeholder' assumed a prominent place in public and non profit management theory and practice in the last 20 years, and especially in the last decade" (Bryson, 2004 , p. 22). The stakeholder concept started to obtain a significant place also in the university management and marketing. Lots of authors and international organizations devote their researches and articles to the stakeholder management in tertiary education sector and strategic management of the tertiary education - for example Paris (2003), Eurydice (2008), Marić (2013), Wagner, Hassanein, Head (2008), Anderson, Iriggs, Burton (2001), Lumby, Foskett (1999), Mainardes, Alves, Raposo (2010), Rowley (1997)Burrows (1999), Franz (1998), Kanji, Tambi (1999), Pereira, Silva (2003), Licata, Frankwick (1996), Rosenmayer (2014) and many others. Although to date no comprehensive research of stakeholders in tertiary education market in the Czech Republic has been performed.

Freeman's definition is probably the most widely accepted basic definition of stakeholder. Freeman states that stakeholders are all 'groups and individuals that can affect, or are affected by, the accomplishment of organizational purpose' (Freeman, 1984, p. 46). Universities are connected with non-profit and public sector, therefore the author seeked also for a specific definition of stakeholder for public and non-profit organiza- 
tions. In the point of view of the public and non-profit sector Bryson defines stakeholders as "any person, group, or organization that can place a claim on an organization"s (or other entity's) attention, resources, or output, or is affected by that output" (Bryson, 2011, p. 48).

Not so long ago, universities were considered as closed entities separated from the external environment (Anderson, Iriggs, Burton 2001), but nowadays they have to interact with large number of stakeholder groups. First of all it is necessary to identify the basic stakeholder groups of universities. The basic stakeholder groups of universities identified based on the literature search are summarised in the following table.

Table 1 Stakeholder Groups of Universities

\begin{tabular}{|c|c|}
\hline Author & Stakeholder groups \\
\hline Burrows & $\begin{array}{l}\text { Management, employees, government entities, clients (students, parents, employers, } \\
\text { employment agencies), government regulators, non-governmental regulators, suppliers, } \\
\text { competition, financial intermediaries, donors, communities, alliances and partnerships }\end{array}$ \\
\hline Franz & Society, employers, students, families \\
\hline Kanji, Tambi & Students, parents, employers, government, educators (employees), industry \\
\hline Kotler, Fox & $\begin{array}{c}\text { Alumni, prospective students, current students, parents of students, local community, } \\
\text { general public, mass media, legislature and government agencies, foundations, accredita- } \\
\text { tion organizations, staff and administration, regents, faculty, trustees, competitors, suppli- } \\
\text { ers, business community, grant organizations and donors }\end{array}$ \\
\hline $\begin{array}{l}\text { Licata, Frank- } \\
\text { wick }\end{array}$ & $\begin{array}{l}\text { Students, former students, general public, parents, local and business community, donors, } \\
\text { teachers and administrative staff, marketing department, government }\end{array}$ \\
\hline Pereira, Silva & $\begin{array}{l}\text { Students, alumni, families, faculty, employers, managers, employees, suppliers, govern- } \\
\text { ment, society, competitors, community group, council }\end{array}$ \\
\hline Rowley & $\begin{array}{c}\text { Students, families and parents, local authorities, local communities, government, media, } \\
\text { societies }\end{array}$ \\
\hline $\begin{array}{l}\text { Smith, Ca- } \\
\text { vusgil }\end{array}$ & $\begin{array}{l}\text { Suppliers (of products, services and founding), media a public relations professionals, } \\
\text { students, employers, student parents, community }\end{array}$ \\
\hline Světlík & Local community, media, general public, students \\
\hline Weaver & $\begin{array}{c}\text { Students, families of students, institutional management, teaching staff, government, } \\
\text { general society }\end{array}$ \\
\hline $\begin{array}{l}\text { Lumby, } \\
\text { Foskett }\end{array}$ & State (government), community, parents, customers, students, employers and business \\
\hline $\begin{array}{l}\text { Anderson, } \\
\text { Iriggs, Burton }\end{array}$ & Parents, industry, business, local community, students (customers), staff, government \\
\hline Marić & $\begin{array}{c}\text { Student, parents, employees, faculty, administrative staff, state and federal government, } \\
\text { communities, financial intermediaries, non-governmental regulators (foundations, institu- } \\
\text { tional accrediting bodies, professional associations), government regulators, Ministry of } \\
\text { education, alumni, competitors }\end{array}$ \\
\hline $\begin{array}{l}\text { Slantcheva, } \\
\text { Levy }\end{array}$ & $\begin{array}{l}\text { Accreditation authorities, ministry of education, government, legislators, donors and } \\
\text { foundations, international associations, non-governmental organizations. }\end{array}$ \\
\hline $\begin{array}{l}\text { Miroiu, An- } \\
\text { dreescu }\end{array}$ & Students, employers, government, agencies, ministry \\
\hline Zait & $\begin{array}{l}\text { Future university candidates (prospective students), present students, university profes- } \\
\text { sors, employers, public }\end{array}$ \\
\hline
\end{tabular}


Source: Burrows (1999), Franz (1998), Kanji, Tambi (1999), Kotler, Fox (2002), Mainardes, Alves, Raposo (2010, 2013), Mainardes, Raposo, Alves, H., (2012), Pereira, Silva (2003), Rowley (1997), Weaver (1976), Slabá (2012), Licata, Frankwick (1996), Smith, Cavusgil (1984), Světlík (2006), Světlik (2009), Lumby, Foskett (1999), Anderson, Iriggs, Burton (2001), Marić (2013), Slantcheva, Levy (2007), Miroiu, Andreescu, (2010), Zait (2006)

Nearly all authors identified the following stakeholder groups as university stakeholder groups:

- Students (as customers of university), community, local community or society, parents (or families of students) (except Světlík), government (except Světlík and Smith and Cavusgil).

On one hand, there are the same stakeholder groups for universities as well as other commercial and non-commercial entities - for example:

- Community, competitors, government, local authorities, media, employees, suppliers, general public, etc.

These stakeholder groups are typical for all commercial (Freeman, 2010; Buysse, Verbeke, 2003) and non-commercial entities (Bryson, 2004; Johnson, Scholes, Whittington, 2008). On the other hand, there are several specific stakeholder groups that are typical only for universities. Competitors are one of the most important stakeholder groups in business (Freeman 2010). In the case of universities there are only four authors that involve competitors in the university stakeholder groups. There are several reasons for this fact - education has elements of both public and commercial goods (Lumby, Foskett, 1999), and in spite of the growing competitive fight, lots of universities do not care about their competition. Government and local authorities are stakeholder groups for profit as well as non-profit organizations.

There are several special stakeholder groups for universities. Among these stakeholder groups the following can be included:

- Ministries of education, alumni, or accreditation authorities.

Donors and grant agencies represent key stakeholder groups for survival of universities.

Table 1 supports the fact that there are lots of stakeholder groups of universities depending on many different aspects - goals, mission competitive position of university, etc. Stakeholder groups may be classified as primary or secondary, internal or external, academic or non-academic, individual or collective, based on their needs, expectations, power of influence etc. (Mainardes, Alves, Raposo, 2013; Freeman, 2010; Hillman, Keim, 2001). For the purpose of this paper, the author will focus on the classification of stakeholders into the groups of primary and secondary and internal and external stakeholder groups.

Primary stakeholders are the most important stakeholders for universities who have to be engaged in all decisions of the university. Primary stakeholders can be defined as those stakeholders "who bear some form of risk as a result of having invested some form of capital, human or financial, something of value, in a firm" (Clarkson, 1994, p. 5). Primary stakeholders are essential for the survival of any organizations (Clarkson, 
1995). Primary stakeholders are represented shareholders, employees, suppliers, customers, or clients, distributors, community, investors and government authorities (Hillman, Keim, 2001; Laan, Ees, Witteloostuijn, 2008). Primary stakeholders are sometimes called 'private' stakeholders and secondary stakeholders are called 'public' stakeholders (Laan, Ees, Witteloostuijn, 2008). From another point of view, "primary stakeholders are those who have a reciprocal and direct exchange relationship with the corporation, whereas secondary stakeholders try to influence these exchange relationships much more indirectly" (Laan, Ees, Witteloostuijn, 2008, p. 302). Therefore, Laan, Ees and Witteloostuijn argue that secondary stakeholders are those "who do not have frequent and direct exchange with the firm' stakeholders" (Laan, Ees, Witteloostuijn, 2008, p. 301). In contrast with primary stakeholders, it is typical for secondary stakeholders that they depend on the organization when it comes to realization of their goals, aims and needs, but the organization is not crucially dependent upon these stakeholders. Relationships with secondary stakeholders are typically characterized by an imbalance of power. On the other hand, primary stakeholders depend on the organization and organization depends on them and the power is in balance.

Basically speaking, internal stakeholders are stakeholders inside an organization (for example management, shareholders, staff, etc.) and external stakeholders are stakeholders outside an organization (for example society, suppliers, government, competitors, media, etc.) (Plessis, Gerber, 2009). In the case of customers, there is an inconsistency in the non-inclusion of internal and external stakeholder groups among different authors. Plessis and Gerber claim that customers are external stakeholder group (Plessis, Gerber, 2009), Chinyio, Freeman and for example Eesley and Lenox include customers into internal stakeholder groups (Chinyio et al., 2010, Freeman 2010, Eesley, Lenox, 2006). Similar situation is for example in the case of suppliers, too. In the case of internal stakeholder groups, it is necessary not only to pay sufficient attention to the appropriate communication, but it is important to focus on the inter-organizational trust as stated by Fiala, Prokop and Živelová, too (2012).These stakeholder groups directly participate in the company performance that is affected by the inter-organizational trust (Fiala, Prokop, Živelová, 2012).

The aim of this paper is identification and analysis of the key stakeholder groups of public and private universities in the Czech Republic. An analysis of stakeholder groups of public and private universities will involve categorization and prioritization for identification of key stakeholder groups of universities. Key stakeholders represent stakeholders with potential risk. Key stakeholders have the power to influence the success or failure of the organization, and can be defined as stakeholders who have the power to prevent the organization from achieving its objectives and potentially may cause the organization goals to fail (Mosaic, 2015).

Categorization of stakeholder groups can be made in variety ways. Each stakeholder group can be considered as one category and divided into sub-categories (Plessis, Gerber, 2009). For example the stakeholder group (category) of employees includes the following groups (in the case of universities) - academic staff, non-academic staff, managers, administration staff, etc. As we can see, there will be an enormous number of stakeholder groups in this case, hence for the author's research, stakeholder groups will be categorized into groups of internal and external, primary and secondary stakeholders. 
Identification and prioritization of stakeholder groups are essential steps of stakeholder analysis towards establishing a significant competitive advantage of any university in the turbulent market of tertiary education with extremely growing competition. In spite of the fact that several authors abroad deal with the identification and analysis of stakeholders of universities (for example Weaver, Burrows, Franz, Rowley, etc.), there was no empirical research of stakeholder groups of universities in the Czech Republic. The Identification, categorization and prioritization of the key stakeholder groups of public and private universities in the Czech market and identification of differences between stakeholder groups of public and private universities are the main problem areas of the author's research (based on the discussion above).

\section{Methods}

In the line with all aspects and facts mentioned above, this article focuses on the stakeholder groups of public and private universities in the Czech Republic. The author's research focused on the identification and prioritization of key stakeholder groups of public and private universities and their basic categorization. The main purpose of this paper is to confirm the suitability of stakeholder groups of universities as identified based on the literature search for needs of the Czech market of tertiary education and identification of key stakeholder groups of public and private universities. For this purpose, the author conducted a research in the Czech market of tertiary education. The fact that nobody has performed an adequate primary research of stakeholders of universities in the Czech Republic so far makes this paper contributive. The main research questions and problems of this paper are as follows:

- Who are the stakeholders of universities in the Czech market?

- Are there any differences among generic stakeholder groups of public and private universities?

- What priorities are assigned to key stakeholder groups of public and private universities?

- Are there any differences between prioritization of stakeholder groups of private and public universities?

Based on the results of the research the main research problem of whether there are differences between key stakeholder groups of public and private universities and their priorities will be verified.

The whole process of the author's research of stakeholder groups of public and private universities in the Czech Republic can be described in following steps:

1. Identification of stakeholders - preparation of the list of stakeholder groups of universities based on literature search;

2. Adaptation of the processed list to the needs of the Czech market of tertiary education and author's research;

3. Identification of key stakeholder groups of public and private universities in the Czech Republic based on the author' research;

4. Categorization of stakeholders into groups of primary and secondary stakeholder groups and internal and external stakeholder groups; 
5. Prioritization of key stakeholder groups of public and private universities in the Czech Republic;

6. Identification of differences among priorities assigned to stakeholder groups by public and private universities.

For the first step of identification of stakeholder groups of universities, to determine literature review of international literature sources (monographs, journal, papers, research articles, books, conference papers, statistics, etc.) was one of the most efficient ways to locate sound evidences on the all significant stakeholder groups. During this first step author processes a large list of different stakeholder groups (for detail see Table 1).

The second part of the first step of identification comprised of an adaptation of the identified stakeholder groups that were identified in the first step of identification to the needs of the Czech universities. The modified list of stakeholders for author's research is as follows:

- Accreditation commission Czech Republic;

- Alumni;

- Communities;

- Competitors;

- Current students;

- Donors and grant organizations;

- Employers;

- Faculties and employees;

- Government authorities;

- High schools;

- Local government;

- Management;

- Marketing and public relations departments;

- Media,

- Ministry of Education, Youth and Sports;

- Parents;

- Prospective students.

Prioritization is the second step after identification of the stakeholder groups. Prioritization will be based on the professional judgment of respondents. The author will calculate priorities based on the following formula:

$$
\text { Total points }=\sum_{i=1}^{18}(18-i) * n(1)
$$

\footnotetext{
Legend:

i.... stakeholder position in individual ranking of priority

n... number of occurrences of a given position of priority

18... maximum number of stakeholder groups
} 
Based on the formula 1, each stakeholder group will obtain total points based on the position in individual ranking of priority and number of occurrences of this priority in total ranking. The stakeholder group with highest points will be considered as the stakeholder group with highest priority - that means priority 1 .

For analysis of data, basic statistical methods will be used - absolute, relative frequency and standard deviation as a measure of variability.

Online survey was chosen as the most effective way for obtaining data. The research sample comprising private and public universities consisted of 39 universities operating in the Czech Republic. There are three types of universities in the Czech Republic private universities, public universities and state universities. In these days, there are 44 private universities, 26 public universities and 2 state universities. The research sample involved 22 private universities and 17 public universities. Representatives of the universities focusing on marketing or external relationships were chosen as respondents for the author's research. The total return rate of questionnaire for both public and private universities was more than $50 \%-56.41 \%$ to be precise. All questions concerning identification and prioritization of stakeholder groups were multiple choice questions with the possibility of multiple answers. In the case that some of the important stakeholder groups were missing, respondents could use choice 'Other'. All choices in author's questionnaire were arranged alphabetically. The total amount of defined stakeholder groups was $17+1$ (other). For prioritization respondents used a scale from 1 to 18 (1 represented the highest priority, 18 represented the lowest priority).

Author will use t-test for identification if the priorities assigned by public and private universities to the stakeholder groups are significantly different from each other (Altman, 1991).

\section{Results of Author's Research}

First of all, the author submitted a list of identified stakeholders to the respondents who selected stakeholder groups important for their university. The purpose of this part of author research was to answer the first research question "Who are the stakeholders of universities in the Czech market?" The results of identification of stakeholders are summarized separately for public and private universities in tables 2 and 3. Stakeholder groups of public and private universities were analysed separately to answer second research question that attempted to find any differences among the stakeholder groups of public and private universities.

The following tables analyze frequency of the respondents' answer. Relative frequency of answers will be used for comparison of public and private universities.

As expected, all stakeholder groups were checked by several respondents. Based on the results summarized in Table 2, we are therefore able to claim that all selected stakeholder groups are more or less important for public universities. All respondents from public universities checked only one group of stakeholders - prospective students prospective students represent clients of universities (customers from the universities point of view). 15 respondents from the total number of 17 public universities checked media. Alumni (76.5\%), too, are among the frequented stakeholder groups, followed by 
current students (70.6\%), and parents (64.7\% of respondents). More than 50 percent of public universities ( 9 of them) consider communities (society) to be a stakeholder group, too. Only 2 respondents checked employers. This fact means that only 2 of the public universities surveyed focus some of their activities toward this stakeholder group. None of respondents used the possibility of "other". From this fact resulted that all public universities considered the list of stakeholders to be a complete list of stakeholder groups of public universities, and there was no necessity to add any other stakeholder group to this list of stakeholders.

Table 2 Results of Identification of Stakeholder Groups of Public Universities in the Czech Republic

\begin{tabular}{l|c|c}
\hline Stakeholder group & Absolute frequency & $\begin{array}{c}\text { Relative frequency } \\
\text { (in \%) }\end{array}$ \\
\hline Accreditation commission Czech Republic & 7 & 41.2 \\
\hline Alumni & 13 & 76.5 \\
\hline Communities & 9 & 52.9 \\
\hline Competitors & 5 & 29.4 \\
\hline Current students & 12 & 70.6 \\
\hline Donors, grant organizations & 4 & 23.5 \\
\hline Employers & 2 & 11.8 \\
\hline Faculties and employees & 7 & 41.2 \\
\hline Government authorities & 10 & 58.8 \\
\hline High schools & 9 & 52.9 \\
\hline Local authorities & 8 & 47.1 \\
\hline Management & 6 & 35.3 \\
\hline Marketing and public relations departments & 3 & 17.6 \\
\hline Media & 15 & 88.2 \\
\hline Ministry of Education, Youth and Sports & 14 & 82.4 \\
\hline Parents & 11 & 64.7 \\
\hline Prospective students & 17 & 100.0 \\
\hline Other & 0 & 0.0 \\
\hline Source: author's research & & \\
\hline
\end{tabular}

Source: author's research

In the context of the previous table, it is necessary to point out that also in this case all stakeholder groups were checked by respondents from private universities. In other words, we can state that the list of selected stakeholder groups was considered complete by private universities. Only one respondent suggested adding one group of stakeholders, namely sponsors. In the context of the list, it is possible and more than appropriate to involve this stakeholder group to the group of donors and grant organizations. As in the case of public universities also all private universities checked only one stakeholder group - prospective students. Nearly all private universities (95.5\% of respondents) chose current students and Ministry of Education, Youth and Sports as stakeholder groups of their university. $91 \%$ of respondents checked media, local authorities and management. More than $80 \%$ of respondents identified. Also in the case of private universities a little attention is devoted to employers, marketing and public relations departments and donors. 
Table 3 Results of Identification of Stakeholder Groups of Private Universities in the Czech Republic

\begin{tabular}{l|c|c}
\hline Stakeholder group & Absolute frequency & $\begin{array}{c}\text { Relative frequency } \\
\text { (in \%) }\end{array}$ \\
\hline Accreditation commission Czech Republic & 9 & 40.9 \\
\hline Alumni & 19 & 86.4 \\
\hline Communities & 11 & 50.0 \\
\hline Competitors & 10 & 45.5 \\
\hline Current students & 21 & 95.5 \\
\hline Donors, grant organizations & 8 & 36.4 \\
\hline Employers & 2 & 9.1 \\
\hline Faculties and employees & 11 & 50.0 \\
\hline Government authorities & 17 & 77.3 \\
\hline High schools & 13 & 59.1 \\
\hline Local authorities & 20 & 90.9 \\
\hline Management & 20 & 90.9 \\
\hline Marketing and public relations departments & 6 & 27.3 \\
\hline Media & 20 & 90.9 \\
\hline Ministry of Education, Youth and Sports & 21 & 95.5 \\
\hline Parents & 14 & 63.6 \\
\hline Prospective students & 22 & 100.0 \\
\hline Other & 0 & 0.0 \\
\hline Source: author's research & & \\
\hline
\end{tabular}

Source: author's research

The "summary" patterns of stakeholder groups are similar for both - public and private universities. Research findings show that there are no significant differences among stakeholder groups of public and private universities. As would have been expected, all suggested stakeholder groups were identified by both public and private universities. Both types of universities have to face the new environment and changes in the market of tertiary education in the Czech Republic, and it is therefore not a startling revelation that all private and public universities choose prospective students. There are really only very slight differences between answers of private and public universities. In both cases, prospective students are mentioned as the most frequented stakeholder group. Media are the second most frequented stakeholder group for public universities and third for private universities. In comparison to public universities, private universities paid more attention not only to alumni, but mainly to current students (current students were checked by $95.5 \%$ of private universities in comparison to $70.6 \%$ of public universities). Both (alumni and current students) are an important carrier of the positive Word of Mouth (further only WOM) of universities. WOM is one of the most important positive tools of marketing communication of universities (Davies, Ellison, 2003). A great part of respondents surveyed (64.7\% of public universities and $63.6 \%$ of private universities) also identify parents. Because lots of prospective students are high schools graduates, it is necessary also to pay attention to high schools and their study referents. Both types of universities pay small attention to employers (employers represents all potential employers of universities' alumni). Employers as the stakeholder group were chosen only by 2 public and 2 private universities. In spite of the fact that competition in the market of tertiary education is still increasing, only $29.4 \%$ of public universities and $45.5 \%$ of 
private universities identify competitors as an important stakeholder group of universities.

Results of this part of research show that the most frequented stakeholder groups are nearly the same for both (public and private) types of universities - prospective students, media, Ministry of Education, Youth and Sports, alumni and current students. On the other hand, employers, donors, competitors and marketing and public relations departments are infrequent stakeholder groups. This problem is further analyzed and results are summarized in the discussion and Table 6. Within categorization, stakeholders will be divided into primary, secondary, internal and external stakeholder groups.

Table 4 Categorization of Stakeholders

\begin{tabular}{|l|c|c|c|c|}
\hline \multicolumn{1}{|c|}{ Stakeholder group } & Primary & Secondary & Internal & External \\
\hline Accreditation commission Czech Republic & $\checkmark$ & & & $\checkmark$ \\
Alumni & $\checkmark$ & & & $\checkmark$ \\
\hline Communities & & $\checkmark$ & & $\checkmark$ \\
Competitors & $\checkmark$ & $\checkmark$ & & $\checkmark$ \\
\hline Current students & $\checkmark$ & & $\checkmark$ & \\
\hline Donors, grant organizations & $\checkmark$ & $\checkmark$ & & $\checkmark$ \\
\hline Employers & & $\checkmark$ & $\checkmark$ & \\
\hline Faculties and employees & & $\checkmark$ & & $\checkmark$ \\
Government authorities & & $\checkmark$ & & $\checkmark$ \\
\hline High schools & $\checkmark$ & & $\checkmark$ & \\
\hline Local authorities & $\checkmark$ & & $\checkmark$ & \\
\hline Management & & $\checkmark$ & & $\checkmark$ \\
Marketing and public relations departments & $\checkmark$ & & & $\checkmark$ \\
Media & $\checkmark$ & & & $\checkmark$ \\
\hline Ministry of Education, Youth and Sports & $\checkmark$ & & & $\checkmark$ \\
Parents & & & & \\
\hline Prospective students & & & $\checkmark$ \\
\hline Source: Auhor & & & \\
\hline
\end{tabular}

Source: Author

There were no many problems with categorization of stakeholders into groups of internal and external stakeholders. There are only four internal stakeholder groups - faculties and employees, management, marketing and public relations departments and current students. But as stated in introduction, there are several discrepancies in categorization of several stakeholder groups. One of them is a group of suppliers. This stakeholder group is not very important stakeholder group for universities (only four authors include suppliers to the stakeholder groups of universities), therefore this stakeholder group was not included into the research and no respondent used possibility other to add this stakeholder group. The second stakeholder group is a group of customers in the case of universities - current and prospective students. There is a discrepancy in the understanding of the position of students as customers for universities. Current students represent current customers and they are therefore considered to be an internal stakeholder group. But $96 \%$ of respondents included prospective students into external stakeholder groups. Current students are really closely connected to university, they represent a part of university with close direct relationship to university; it is therefore clear that they are understood as internal groups. Prospective students represent possible future students 
who are not in direct close connection, and this is probably the reason why respondents categorized them as an external group.

Now we will focus on further analysis - prioritization of stakeholder groups. The formula for calculating of the priorities will be modified as follows (see next formula for details).

$$
\text { Total points }=\sum_{i=1}^{17}(17-i) * n(2)
$$

The comparison of priorities assigned to stakeholder groups by public and private universities is shown in the following figure.

\section{Figure 1 Priorities of Stakeholder Groups}

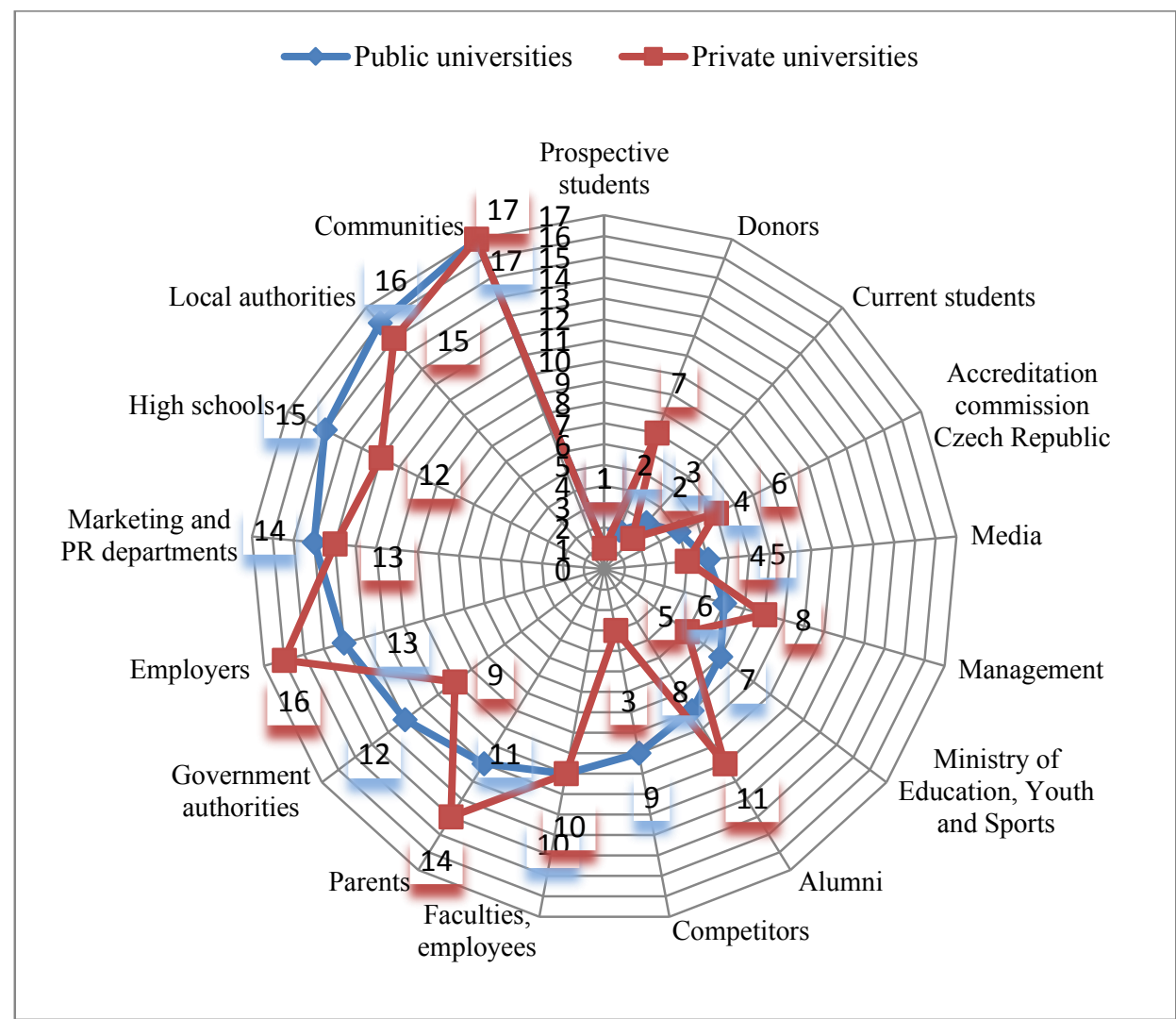

Source: author's research

Note: Stakeholder groups are ranged in the figure clockwise based on their priorities. The closer a stakeholder group is to the centre of the figure, the more important this group for the university is. 
As can be seen form Figure 1 and the Table 5 there are only 3 stakeholder groups that have the same priority for both - public and private universities - prospective students, communities and faculties and employees. Prospective students are considered to be the most important stakeholder group for both public and private universities. On the other hand, communities are considered by both types of universities as the less important stakeholder group. Stakeholder group of current students is the second most important stakeholder group for private universities. Based on priorities, current students were assigned the third position by public universities, whilst donors were considered to be the second most important stakeholder group. As mentioned above in the introduction, there are lots of changes in the market of tertiary education. These changes are connected to demographic trends and decrease in public expenditures on educational institutions, etc. Because of the decrease in public expenditures, universities have to search for new sources of funding. Tuition is one of the most important sources of funding for private universities. Tuition at public universities is a matter of long-term political debates, but it has not been implemented in practice yet. Public universities have to search for different sources, donors, etc. that are very important for their survival. Public universities recognize the importance of donors as key stakeholder group, but on the other hand, they underestimate competitors slightly. Competitors were considered to be the ninth most important stakeholder group, while private universities indicated competitors as the third most important stakeholder group.

However, the overall responses of public and private universities are not different too much. The biggest difference in priorities between public and private universities is in the case of competitors and donors. For overall evaluation, it is also important to determine how different the responses of the respondents in both groups were. In order to carry out a detailed analysis the author used standard deviation calculated for public universities, private universities and total standard deviation (see table 5 for details). Standard deviation indicates how the answers of respondents are spread far from the mean.

The zero standard deviation was calculated only for prospective students who are the most important stakeholder group for both types of universities (assigned priority 1). Most of the stakeholder groups have a small standard deviation that indicates that the answers of respondents are clustered closely around the mean. The total maximum standard deviation does not exceed 2.5. The highest standard deviation was calculated for donors and grant organizations followed by competitors. The maximum standard deviation was calculated for donors of private universities. Priorities assigned to the donors (for private universities) deviate from the mean to a greatest extent. A very low standard deviation was calculated also for the following stakeholder groups: media, communities, current students and faculties and employees.

Calculated standard deviation in all groups - public universities, private universities, as well as total standard deviation for both - confirms the fact that in groups, there are only slight differences among respondents opinion. The highest discrepancy is connected to the stakeholder group of parents for public universities, where the answers are spread quite far from the mean, and the standard deviation is nearly 4. 
Table 5 Calculated Priorities and Standard Deviation

\begin{tabular}{|c|c|c|c|c|c|}
\hline Stakeholder group & $\begin{array}{l}\text { Public universi- } \\
\text { ties }^{1)}\end{array}$ & $\begin{array}{l}\text { Private univer- } \\
\quad \text { sities }^{1)}\end{array}$ & $\begin{array}{c}\text { Standard } \\
\text { deviation } \\
\text { for public } 2)\end{array}$ & $\begin{array}{c}\text { Standard } \\
\text { deviation } \\
\text { for private } 2 \text { ) }\end{array}$ & $\begin{array}{l}\text { Total stand- } \\
\text { ard devia- } \\
\text { tion²) }\end{array}$ \\
\hline $\begin{array}{l}\text { Accreditation commis- } \\
\text { sion Czech Republic }\end{array}$ & 4 & 6 & 1.05 & 1.33 & 1.22 \\
\hline Alumni & 8 & 11 & 0.98 & 2.01 & 1.51 \\
\hline Communities & 17 & 17 & 0.56 & 1.02 & 0.44 \\
\hline Competitors & 9 & 3 & 3.89 & 0.98 & 2.44 \\
\hline Current students & 3 & 2 & 0.5 & 0.5 & 0.50 \\
\hline $\begin{array}{l}\text { Donors, grant organiza- } \\
\text { tions }\end{array}$ & 2 & 7 & 1.51 & 3.32 & 2.45 \\
\hline Employers & 13 & 16 & 1.31 & 1.36 & 1.34 \\
\hline $\begin{array}{l}\text { Faculties and employ- } \\
\text { ees }\end{array}$ & 10 & 10 & 0.21 & 0.56 & 0.38 \\
\hline Government authorities & 12 & 9 & 1.57 & 1.69 & 1.62 \\
\hline High schools & 15 & 12 & 1.19 & 1.36 & 1.46 \\
\hline Local authorities & 16 & 15 & 1.12 & 1.14 & 1.11 \\
\hline Management & 6 & 8 & 1.12 & 0.89 & 1.55 \\
\hline $\begin{array}{l}\text { Marketing and public } \\
\text { relations departments }\end{array}$ & 14 & 13 & 1.23 & 0.76 & 1.21 \\
\hline Media & 5 & 4 & 0.45 & 0.89 & 0.70 \\
\hline $\begin{array}{l}\text { Ministry of Education, } \\
\text { Youth and Sports }\end{array}$ & 7 & 5 & 0.79 & 1.05 & 0.89 \\
\hline Parents & 11 & 14 & 2.09 & 1.69 & 1.88 \\
\hline Prospective students & 1 & 1 & 0 & 0 & 0 \\
\hline
\end{tabular}

1) based on the formula $2,{ }^{2)}$ calculated from the answers of respondents

Source: author's research

\section{Discussion}

The stakeholder analysis is one of the modern methods used in management and marketing. Stakeholder analysis is capable of identifying the most important stakeholder groups with direct and indirect influence on the organization. Therefore, the aim of this paper was carry out an identification, categorization and prioritization (key steps of stakeholder analysis) of key stakeholder groups in the Czech market of tertiary education and reveal possible differences between stakeholder groups of public and private universities. A comparison of 5 most frequent stakeholder groups of public and private universities follows in Table 6.

Prospective students, media, Ministry of Education, Youth and Sports, alumni and current students are the most frequent stakeholder groups of public universities. Current students who are considered to be the second most frequent stakeholder group of private universities are the fifth most frequent stakeholder group of public universities. Only prospective students were checked by all private and public universities. 
Table 6 Comparison of 5 Most Frequent Stakeholder Groups of Public and Private Universities

\begin{tabular}{l|c|c}
\hline Stakeholder group & Public universities & Private universities \\
\hline Prospective students & 100 & 100 \\
Media & 88.2 & 90.9 \\
Ministry of Education, Youth and Sports & 82.4 & 95.5 \\
Alumni & 76.4 & 86.4 \\
Current students & 70.6 & 95.5 \\
Management & & 90.9 \\
Local authorities & & 90.9 \\
Government authorities & & 77.3 \\
\hline
\end{tabular}

Note: 1) all answers are in \%,

Source: author's research

Since private universities have several stakeholder groups with the same frequency, there are more than five most important stakeholder groups. For private universities, prospective students are the most frequent stakeholder group, Ministry of Education, Youth and Sports and current students are the second most frequent stakeholder groups, media, management and local authorities are the third most frequent stakeholder group, alumni are the fourth, and finally government authorities are the fifth most frequent stakeholder group. We can see in Table 6 that private universities pay more attention to stakeholder groups. $70.6 \%$ of respondents among public universities identified current students to be the second most frequent stakeholder group. For private universities, current students are considered to be the second most frequent stakeholder group, while for public universities they are the fifth most frequent stakeholder group. Private universities identified management as the third most frequent stakeholder and public universities identified management as the eleventh most frequent stakeholder group of public universities. Management is traditionally connected with business and commercial subject. In spite of the fact that public universities have to use managerial tools to be successful in the competition at the market of tertiary education; public universities are not considered as commercial institution. This fact is probably the main reason of the differences between answers of public and private universities.

The author's research proved that stakeholder groups that had been identified based on the literature search of the foreign sources are appropriate for the Czech market of the tertiary education, too.

To prepare categorization of stakeholder groups in the Czech market of the tertiary education was another objective of this paper (see Figure 2 for details).

T-test was calculated for the five most important stakeholder groups. The results of the t-test are as follows:

Table 7 T-test for Key Stakeholder Groups

\begin{tabular}{l|c|c}
\hline Stakeholder group & $p$-value & t-test \\
\hline Prospective students & - & - \\
Media & 0,0301638 & $-2,25463$ \\
Ministry of Education, Youth and Sports & 0,0000131258 & $-5,03307$ \\
\hline
\end{tabular}




\begin{tabular}{l|l|l}
\hline Alumni & 0,04568 & $-4,3265$ \\
Current students & 0,02364 & $-3,2564$ \\
\hline
\end{tabular}

Source: author's research

The results in the Table 7 indicate that there is a statistically significant difference between the means of the selected samples at the $95.0 \%$ confidence level.

Figure 2 Categorisation of Stakeholder Groups

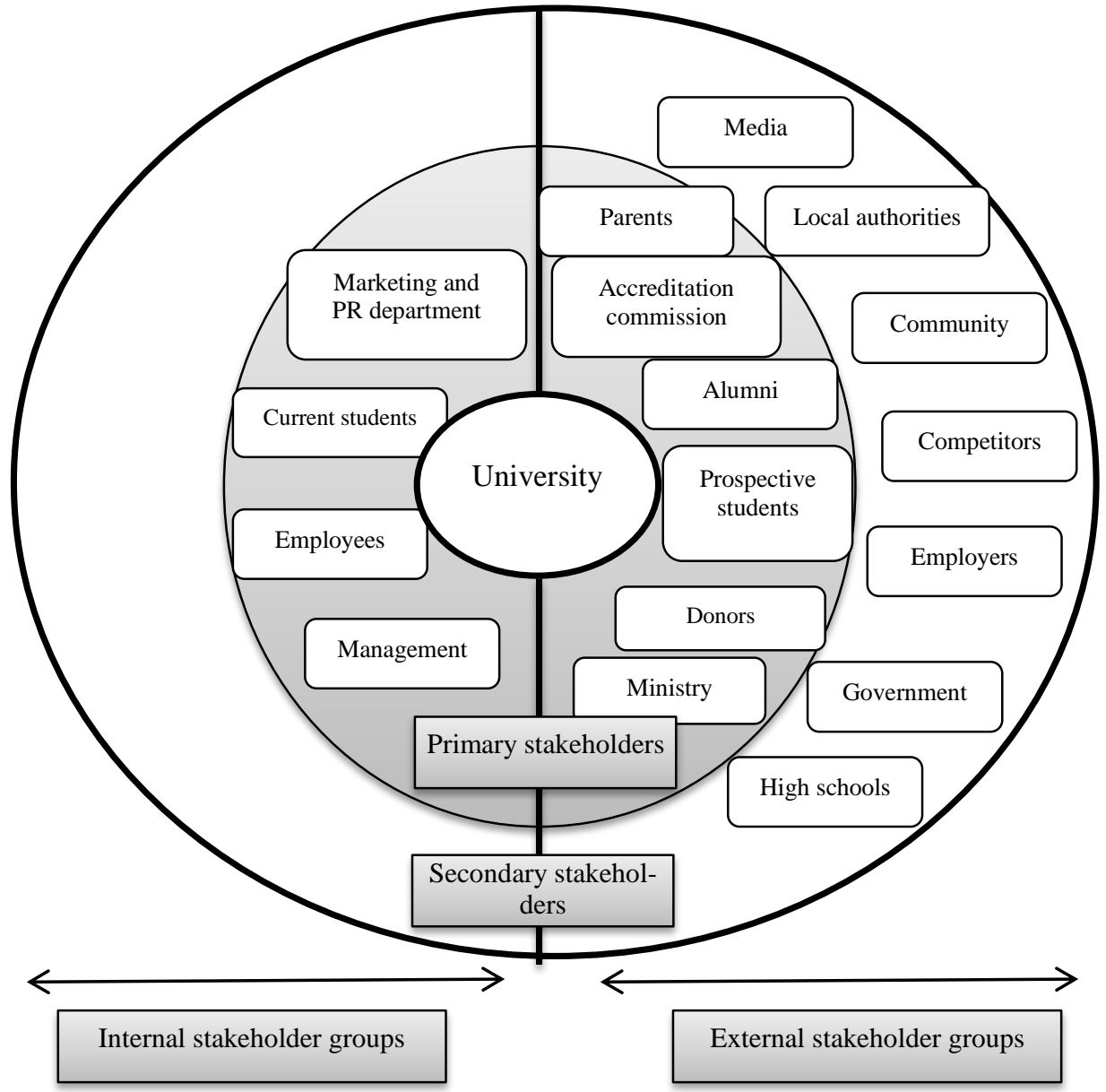

Source: author's research

Legend: stakeholder groups close to the centre (in the grey circle) represent primary stakeholder groups. Stakeholder groups in the second circle (further from the centre) represent secondary stakeholder groups. Stakeholder groups in the left side of the figure are categorized as internal stakeholder groups and in the right side of the figure are external stakeholder groups. 
As we can see from the Figure 1, the stakeholder groups of universities can be divided into four basic groups:

- primary internal stakeholder groups;

- primary external stakeholder groups;

- secondary internal stakeholder groups;

- secondary external stakeholder groups.

Primary internal stakeholder groups of universities represent stakeholder groups that are crucial for survival of universities and involve stakeholder groups that bear risk and investment connected to universities. Primary internal stakeholder groups include employees, management, marketing and PR department, which are responsible for marketing communication and creating long term relationships with all key stakeholder groups and current students. Current students, who are among 3 most important stakeholder groups for public and private universities, are the most important stakeholder group included in primary internal stakeholder groups.

Primary external stakeholder groups of universities include stakeholder groups that are essential for survival of universities, despite not being in direct close relation with the university. These stakeholder groups are in an indirect connection, but have a direct influence on survival of universities. External stakeholders are those stakeholder groups that exist outside university. Primary external stakeholder groups of universities involve alumni, prospective students, parents, as well as donors, Ministry of Education, Youth and Sports and Accreditation commission. These stakeholder groups are crucial for survival of universities but exist outside universities and involve the most important stakeholder group - prospective students. Except for parents, all primary external stakeholder groups are included in the ten most important stakeholder groups of public and private universities based on the prioritisation. Therefore, it is possible to state that these stakeholder groups are the most important from the universities' point of view, and that universities have to pay the highest attention to these stakeholder groups.

No stakeholder groups were identified as secondary internal stakeholder groups. This fact was a subject of deeper examination, and several respondents stated that support staff should be included in this stakeholder group.

Lots of stakeholder groups are included in the secondary external stakeholder groups for example media, community, local authorities, competitors, employers, state government and high schools.

Prioritization of stakeholder groups is another important part of the stakeholder analysis. The prioritization identifies the most important stakeholder groups for universities (see table 5 for details).

Mapping of stakeholder groups is another step of stakeholder analysis. For mapping it is necessary to reduce the number of stakeholder groups. The list of stakeholder groups was limited to ten most important stakeholder groups for public and private universities. The list of ten most important stakeholder groups follows in Table 8. 
Table 8 The Most Important Stakeholder Groups

\begin{tabular}{l|c|c}
\hline \multicolumn{1}{c|}{ Stakeholder group } & Public universities & Private universities \\
\hline Prospective students & 1 & 1 \\
\hline Donors, grant organizations & 2 & 7 \\
\hline Current students & 3 & 2 \\
\hline Accreditation commission Czech Republic & 4 & 4 \\
\hline Media & 5 & 8 \\
\hline Management & 6 & 5 \\
\hline Ministry of Education, Youth and Sports & 7 & 11 \\
\hline Alumni & 8 & 3 \\
\hline Competitors & 9 & 10 \\
\hline Faculties and employees & 10 & 9 \\
\hline Government authorities & 12 & 6 \\
\hline
\end{tabular}

Source: author's research

As we can see, the author identified 10 most important stakeholder groups for public and private universities. There are eight stakeholder groups that were included in ten most important stakeholder groups for both public as well as private universities - prospective students, donors and grant organizations, current students, Accreditation commission Czech Republic, media, management, Ministry of Education, Youth and Sports, competitors and faculties and employees. Alumni are considered to be the eighth most important stakeholder group for public universities; however, they have not been assigned such an importance for private universities and scored priority 11. Government authorities are among 10 most important stakeholder groups for private, but not for public universities.

This list of ten most important stakeholder groups for public and private universities will be used for further research that will focus on stakeholder mapping.

\section{Conclusion}

The main contribution of the paper is the application of the stakeholder analysis on the tertiary education market in the Czech Republic. No similar comprehensive research focusing on the stakeholders in tertiary education has been carried out in the Czech Republic so far. The author's research shows the reality that universities (and mainly public universities) focus on a limited set of stakeholder groups only. Public universities focus mainly on the students, media and Ministry of Education, Youth and Sports. Private universities understand the necessity of communicate with key stakeholder groups a little bit more than public universities. Nine stakeholder groups were chosen by more than $60 \%$ of respondents from private universities, and six stakeholder groups were chosen by more than $90 \%$ of the private universities involved in the survey. In the case of public universities, only 6 stakeholder groups were chosen by more than $60 \%$ of respondents, 3 by more than $80 \%$ of respondents, and only 1 stakeholder group was chosen by more than $90 \%$ of respondents. 
Donors and competitors are the most controversial stakeholder groups. Public universities state that donors are the second most important stakeholder group based on priority, but private universities assigned priority 7 to donors. A similar situation is in the case of competitors. Public universities assigned them with priority 9 , private universities priority 3 .

The results of the research show that not all most frequent stakeholder groups are the most important stakeholder groups with highest priorities. For example $95.5 \%$ of private universities marked stakeholder group Ministry of Education, Youth and Sports, but this stakeholder group is considered by the private universities to be the fifth most important based on the priority. On the other hand, competitors were marked by 45.5 private universities, but are considered to be the third most important stakeholder group. To achieve the relevant results, it is necessary to deal not only with identification, but prioritization of stakeholders with regard to the required research focus, too.

The author came to the same conclusion as Rosenmayer: Universities (both private and public) have to work with stakeholder groups more efficiently and on a daily basis (Rosenmayer, 2014). Universities have to focus more on several stakeholder groups competitors and donors from the external stakeholder groups and employees from the internal stakeholder groups because employees are one of the most important elements of services.

For further research it was necessary to identify 10 most important stakeholder groups based on priority. These stakeholder groups will be used for the third step of stakeholder analysis - stakeholder mapping. Ten most important stakeholder groups are similar for both - public as well as private universities. Only government authorities are included in ten most important stakeholder groups of private universities, but they are not included in ten most important stakeholder groups of public universities based on priority. Differences in priority range from 1 degree to three degrees. The identified stakeholder groups will be included in another research that will focus on the stakeholder mapping. For mapping it is possible to use different types of matrixes and grids - for example, power-interest matrix, influence-attitude matrix, three dimensional maps, stakeholderresponsibility matrix and many others.

\section{References}

ALTMAN, D.G. (1991). Practical Statistics for Medical Research. London: Chapman \& Hall

AMARAL. A., MAGALHÃES.A. (2002). The Emergent Role of External Stakeholders in European Higher Education Governance. Governing Higher Education: National Perspectives on Institutional Governance. Higher Education Dynamics.2002 (2). Pp. 121. DOI: $10.1007 / 978-94-015-9946-7$

ANDERSON L. IRIGGS. A. R. J.. BURTON. N. (2001). Managing Finance. Resources and Stakeholders in Education. London: Paul Chapman Publishing

BRYSON. J. M. (2004). What to do when Stakeholders Matter? Stakeholder Identification and Analysis Techniques. Public Management Review.6(1). pp. 21-53. 
BRYSON. J. M. (2011). Strategic Planning for Public and Nonprofit Organizations: A Guide to Strengthening and Sustaining Organizational Achievement. San Francisco: John Wiley \&Sons.

BURROWS, J.(1999).Going Beyond Labels: A Framework for Profiling Institutional Stakeholders. Contemporary Education.70(4). Pp. 5-10.

BURTON. C. (2001). The Entrepreneurial University: New Foundations for Collegiality, Autonomy, and Achievement. Journal of the Programme on Institutional management in Higher Education 13(2). Pp. 9-24

BUYSSE, K., VERBEKE, A. (2003). Proactive Environmental Strategies: A Stakeholder Management Perspective. Strategic Management Journal. 24 (5). Pp. 453-470.

CHINYIO. E. et al. (2010). Construction Stakeholder Management. Chichester: Blackwell Publishing.

CLARKSON.M. (1994). A risk based model of stakeholder theory: Toronto. Proceedings of the Second Toronto Conference on Stakeholder Theory. Centre for Corporate Social Performance and Ethics, University of Toronto: Toronto.

CLARKSON.M. (1995). A stakeholder framework for analysing and evaluating corporate social performance. Academy of Management Review 20 (1). Pp. 92-117.

EESLEY. C., LENOX.M. (2006). Firm Responses to Secondary Stakeholder Action.Strategic Management Journal. 27(8). Pp. 765-781

EURYDICE (2008).Higher Education Governance in Europe Policies. structures. funding and academic staff. Brussels: Eurydice. ISBN 978-92-79-08524-6

FIALA. R., PROKOP. M., ŽIVĚLOVÁ, I. (2012). The relationship between interorganizational trust and performance. Acta universitatis agriculturae Mendelianae Brunensis. 55(4). Pp. 89-98.

FRANZ, R. (1998). Whatever you do, don't treat your students like customers! Journal of Management Education. 22(1). Pp. 63-69. DOI: 10.1177/105256299802200105

FREEMAN. R. E. (1984). Strategic Management: A Stakeholder Approach. Massachusetts. USA: Pitman Publishing Company.

FREEMAN. R. E. (2010). Strategic Management: A Stakeholder Approach. Cambridge: Cambridge University Press.

HILLMAN. A. J., KEIM. G. D. (2001). Shareholder value, stakeholder management, and social issues: What's the bottom line? Strategic Management Journal. 22(2). Pp. 125-139. DOI: 10.1002/1097-0266(200101)22:2<125::AID-SMJ150>3.0.CO;2-H

JOHNSON, G., SCHOLES, K., WHITTINGTON, R. (2008). Exploring Corporate Strategy. Text and Cases. Harlow: Financial Times / Prentice Hall.

KANJI, G. K., TAMBI, M. B. A. (1999). Total quality management in UK higher education institution. Total Quality Management. 10(1). Pp. 129-153. DOI: $\underline{10.1080 / 0954412998126}$ 
KOTLER, P., FOX, K. (2002).Strategic Marketing For Educational Institutions. New Jersey: Prentice-Hall.

LAAN, VAN DER G., EES VAN H., WITTELOOSTUIJN Van A. (2008). Corporate Social and Financial Performance: An Extended Stakeholder Theory, and Empirical Test with Accounting Measures. Journal of Business Ethics. 79 (3).Pp. 299-310. DOI: $\underline{10.1007 / \mathrm{s} 10551-007-9398-0}$

LICATA, J., FRANKWICK, G. (1996). University marketing: a professional service organisation perspective. Journal of Marketing for Higher Education. 7(2). Pp. 1-16.

LUMBY. J., FOSKET. N. H. (1999). Managing External Relations in Schools and Colleges: International Dimensions. London: Paul Chapman Publishing.

MAINARDES. W. E..ALVES.H.. RAPOSO.M. (2010). An Exploratory Research on the Stakeholders of University. Journal of Management and Strategy. 10 (1). pp. 76-88.

MAINARDES. W. E..ALVES.H.. RAPOSO.M.(2013). Identifying Stakeholders in a Portuguese university: a case study. Revista de Educación. . 2013 (362). pp. 429-457.

MAINARDES. W. E..RAPOSO.M., ALVES.H.. (2012). Public university students' expectations: an empirical study based on the stakeholders theory. Transylvanian Review of Administrative Science .2012 (35). pp. 173-196.

MARIĆ.I. (2013). Stakeholder analysis of higher education institutions. Interdisciplinary Description of Complex Systems.11(2).Pp. 217-226

MIROIU. A., ANDREESCU. L. (2010).Goals and Instruments of Diversification in Higher Education. Quality Assurance Review.2(2). Pp. 89-101

MOSAIC.(2015). Key Stakeholders. From:

http://www.mosaicprojects.com.au/Mag_Articles/N008_Key_Stakeholders.pdf

OECD. 2013. Education at a Glance 2013: OECD Indicators. OECD Publishing. ISBN 978-92-64-20105-7

PARIS. K.A. (2003). Strategic planning in the university. Madison. WI: Office of Quality Improvement. University of Wisconsin-Madison. Retrieved on July 25. 2007 from: http://kathleenparis.com/ee-assets/my-uploads/docs/Strategic-Planning-\%20inthe-University.pdf

PARK.T. (2011).Academic Capitalism and its Impact on the American Professoriate. The Journal of the Professoriate. An affiliate of the Center for African American Research and Policy.6(1). Pp. 84-99.

PEREIRA, M. A. C., SILVA DA, M. T. (2003). A Key Question for Higher Education: Who are the customers? Proceedings of the 31st Annual Conference of the Production and Operations Management Society. Atlanta. pp. 1-16.

PLESSIS. du N., GERBER. K. (2009). Marketing communication. Cape Town: Pearson Education South Africa Ltd.

ROSENMAYER.T. (2014).Using Data Envelopment Analysis: a Case of Universities. Národohospodářský obzor.14(1). Pp. 34-54. DOI: 10.2478/revecp-2014-0003 
ROWLEY, J. (1997). Beyond service quality dimensions in higher education and towards a service contract. Quality Assurance in Education.5(1). Pp. 7 - 14.

ROWLEY.J. (1997).Beyond service quality dimensions in higher education and towards a service contract. Quality Assurance in Education.5(1). Pp. 7 - 14.

SLANTCHEVA, S. AND LEVY, D. (2007). Private higher education in postcommunist Europe. New York: Macmillan.

SMITH, L., CAVUSGIL, T. (1984).Marketing planning for colleges and universities. Long Range Planning.17(6). Pp. 104-117. DOI: 10.1016/0024-6301(84)90223-1

SVĚTLÍK, J. (2006). Marketingové řizeni školy. Praha: ASPI.

WAGNER. N., HASSANEIN. K., HEAD. M. (2008). Who is responsible for ELearning Success in Higher Education? A Stakeholders' Analysis. Educational Technology \& Society.11(3).Pp. 26-36

WEAVER, T. (1976). What is the good of higher education? Higher Education Review, 8(3). Pp. 3-14.

ZAIT.A.(2006). Higher Education Marketing: Stakeholders' Perceptions, Degree of Trust and Desired Student Abilities - Case of Romania (Preliminary Raw Results). From http://ssrn.com/abstract=982306 